\title{
CRÍTICAS À BARGANHA NO PROCESSO PENAL: INCONSISTÊNCIAS do MOdelo PROPOSTO NO PROJETO de Código de PROCESSO PENAL (PLS 156/2009)
}

Vinicius Gomes de
Vasconcellos
Mayara Cristina
Lippel $^{2}$

\section{Resumo}

Este artigo realizará, a partir de revisão bibliográfica, análise crítica do modelo de justiça criminal negocial proposto pelo projeto de Código de Processo Penal (PLS 156/09), denominado "procedimento sumário". Partindo-se da delimitação introdutória dos conceitos de barganha e processo penal consensual, desenvolver-se-á estudo das características principais de tal modelo, a partir do exemplo estadunidense da plea bargaining e do mecanismo projetado pelo PLS 156/09. Com base nisso, apresentar-se-ão críticas que envolvem a expansão da justiça criminal negocial no ordenamento jurídico brasileiro, as quais configuram problemáticas que esvaziam por completo premissas essenciais do processo penal de um Estado democrático de Direito. Assim, partindo-se do exemplo do "procedimento sumário" do referido projeto, apontar-se-á a ilegitimidade da barganha como instituto consensual na justiça criminal, desvelando-se a incontornável inconstitucionalidade do referido mecanismo.

Palavras-chave: Barganha. Justiça criminal negocial. PLS 156/09. Procedimento sumário. Processo Penal.

\section{INTRODUÇÃO}

Atualmente, afloram-se os debates sobre a grande quantidade de processos e a morosidade em seus julgamentos, sendo pontos de fundamental relevo o crescimento de demandas de atores do Direito Penal e clamores sociais por ações estatais visando acelerar o trâmite processual. Nesse sentido, há a cristalina disseminação e fortalecimento de mecanismos visando à sumarização de procedimentos e à relativização de garantias. Uma das principais alternativas que concretizam essa possibilidade, consagrando as ideias de aceleração e

\footnotetext{
${ }^{1}$ Doutorando em Direito na Universidade de São Paulo (USP). Professor de Direito Penal e Processo Penal nas Faculdades Integradas Campos Salles (SP). E-mail: E-mail: vgomesv@gmail.com

${ }^{2}$ Graduada em Direito pela Universidade de São Paulo (2015). E-mail: mayaralippel@icloud.com vol.09, nº. 03, Rio de Janeiro, 2016. pp. 
simplificação procedimental, é a justiça negocial, essencialmente caracterizada pelo instituto da barganha, a antecipação da punição por meio de acordos entre acusação e defesa, o que caracteriza tendência internacional e presente, inclusive, no âmbito brasileiro (OLIVEIRA, 2015, p. 11-13).

Referido modelo de procedimento fortaleceu-se, essencialmente, nos Estados Unidos, e consiste em um acordo, entre o Ministério Público e a defesa, acerca do reconhecimento da culpabilidade do acusado em momento inicial do processo (ou mesmo em fase pré-processual). Há, verdadeiramente, um escambo entre a conformidade do acusado e algum eventual benefício obtido, concedido pela acusação, de acordo com o juízo (SCHÜNEMANN, 2009, p. 408). Tal prática, inicialmente, padeceu de certas resistências, mas atualmente é reconhecida e legítima na maior parte dos Estados Unidos e nos processos federais. Inclusive, mais de 90 por cento das condenações são obtidas sem a realização do juízo, somente por meio do "plea bargaining".

A barganha conta com propostas de expansão de suas autorizações no ordenamento brasileiro, notadamente no Projeto de Lei do Senado 156 de 2009 (reforma global do Código de Processo Penal), já aprovado em tal casa e remetido à Câmara dos Deputados sob o número PL 8.045/2010, e no Projeto de Lei do Senado Federal 236 de 2012 (reforma global do Código Penal), ambos introduzindo maiores possibilidades de negociações sobre a sanção criminal, por meio de acordos denominados "procedimento sumário" e "barganha", respectivamente, e inspirados em tais tendências internacionais. Além dessas propostas de ampliação, marcantes são os institutos atualmente presentes no campo jurídico-penal pátrio (transação penal e colaboração premiada), que, embora admitidos em casos (em tese) não generalizados - e, assim, supostamente restarem limitados - expõem basilares aporias do processo penal em face aos ditames constitucionais e convencionais.

Diante de tal cenário, este artigo realizará análise crítica do modelo de justiça criminal negocial proposto pelo projeto de Código de Processo Penal (PLS 156/09), denominado "procedimento sumário". Assim, determinam-se os seguintes problemas: 1) a barganha, como expressão da justiça criminal negocial, é mecanismo compatível com a Constituição brasileira de 1988?; e 2) o regramento proposto pelo PLS 156/2009 (8.045/2010) em seu artigo 283 (procedimento sumário) é adequado à sistematização de instituto negocial diante das características do ordenamento brasileiro?

Partindo-se da delimitação introdutória dos conceitos de barganha e processo penal consensual, desenvolver-se-á estudo das características principais de tal modelo, a partir do exemplo estadunidense da plea bargaining e do mecanismo projetado pelo PLS 156/09. Com vol.09, nº 03, Rio de Janeiro, 2016. pp. 
base nisso, apresentar-se-ão críticas que envolvem a expansão da justiça criminal negocial no ordenamento brasileiro, as quais configuram problemáticas que esvaziam por completo premissas essenciais do processo penal de um Estado democrático de Direito. Assim, partindose do exemplo do "procedimento sumário" do referido projeto, apontar-se-á a ilegitimidade da barganha como instituto consensual na justiça criminal, desvelando-se a incontornável inconstitucionalidade do referido mecanismo.

\section{BARGANHA NO PROCESSO PENAL: CONCEITOS INTRODUTÓRIOS E CARACTERÍSTICAS FUNDAMENTAIS DA JUSTIÇA CRIMINAL NEGOCIAL.}

Embora este estudo não almeje uma análise aprofundada da conceituação da barganha e da justiça criminal negocial no processo penal, mas, em realidade, uma análise crítica do modelo proposto em tais termos pelo Projeto de Código de Processo Penal (PLS 156/09), é fundamental delimitar as características fundamentais dos institutos examinados. Tal tarefa, por certo, deve passar, ainda que introdutoriamente, pelo exemplo estadunidense da plea bargaing, o qual, em que pese apresente diferenciações em relação aos seus assemelhados em ordenamentos continentais, inevitavelmente, é a base para o estudo da justiça criminal negocial, além de desvelar pontos criticáveis que também são compartilhados no cenário brasileiro, inclusive.

Para tanto, define-se a justiça criminal negocial (ou consensual) ${ }^{3}$ como "modelo que se pauta pela aceitação (consenso) de ambas as partes - acusação e defesa - a um acordo de colaboração processual com o afastamento do réu de sua posição de resistência, em regra impondo encerramento antecipado, abreviação, supressão integral ou de alguma fase do processo, fundamentalmente com o objetivo de facilitar a imposição de uma sanção penal com algum percentual de redução, o que caracteriza o benefício ao imputado em razão da renúncia ao devido transcorrer do processo penal com todas as garantias a ele inerentes"

\footnotetext{
${ }^{3}$ Diferenciando os conceitos de justiça consensual e negocial, ver: LEITE, 2013, p. 22-23. Tal distinção, entretanto, mostra-se disfuncional à conceituação aqui proposta por dois motivos: por um lado, distancia-se e, assim, ofusca a essência do tema tratado, qual seja, a supressão ou abreviamento do processo; por outro, parece centrar-se em fato que, na verdade, reflete disfuncionalidade na concretização prática da justiça consensual, a coerção característica dos mecanismos negociais em que a vontade do acusado, embora 
(VASCONCELLOS, 2015a, p. 55). Há autores que primam pelo fortalecimento do diálogo e do papel da vítima na justiça criminal, sustentando, aparentemente, a importância de mecanismos de mediação penal (OLIVEIRA, 2015, p. 114-115). ${ }^{4}$ Pensa-se, contudo, que a justiça criminal negocial, conforme as premissas utilizadas neste estudo, acarreta consequências completamente diversas, visto que se realiza por meios (falaciosamente) processuais e jurisdicionalizados, em que a acusação utiliza a coerção inerente ao processo como ferramenta de intimidação e, exatamente, afastamento do diálogo.

Nesse sentido, a barganha é caracterizada como uma espécie de justiça negocial, expressando "um instrumento processual que resulta na renúncia à defesa, por meio da aceitação (e possível colaboração) do réu à acusação, geralmente pressupondo a sua confissão, em troca de algum benefício (em regra, redução de pena), negociado e pactuado entre as partes ou somente esperado pelo acusado" (VASCONCELLOS, 2015a, p. 68). Portanto, a partir de tal delimitação, afirma-se que seus elementos essenciais são a renúncia à defesa, a imposição de uma punição antecipada, bem como a expectativa do réu em receber algum benefício por tal consentimento (ou em evitar uma punição em razão do exercício de seus direitos).

\section{O exemplo estadunidense da plea bargaining. 5}

O sistema processual penal norte americano, ${ }^{6}$ produto da common law, expressa o denominado sistema adversarial, ${ }^{7}$ caracterizando-se pela predominância partes das partes ao longo da marcha processual, havendo acusador contra o acusado, acompanhado, este último, de seu defensor (GROSSI, 2015, p. 141). Acusador e acusado enfrentam-se em igualdade de condições perante um Tribunal, representado por jurados espectadores e com a presidência de um magistrado. Tal sistema é caracterizado pela ampla disponibilidade de seu objeto, o que abre brechas para as negociações entre acusação e defesa, definindo elementos que atraem

presumidamente livre, torna-se imposta circunstancialmente, de modo que a grande maioria, se não a integralidade dos acordos, seriam consensuais e não negociados.

${ }^{4}$ Oliveira (2015, p. 137-164), de modo distinto à mediação penal, também propõe, com algumas ressalvas, a utilização do modelo sustentado por Figueiredo Dias (2011), o qual caracteriza fundamentalmente um mecanismo de barganham nos termos expostos e criticados neste trabalho.

${ }^{5}$ Sobre a importância do estudo da plea bargaining dos Estados Unidos, aponta Jenia Turner (2009, p. 02): "Os diferentes modelos de plea bargaining nas jurisdições federal e estaduais norte-americanas e a longa história da plea bargaining nos Estados Unidos fornecem uma rica experiência e importantes considerações. Além disso, a plea bargaining estadunidense serve de exemplo a diversos outros países na adoção de práticas semelhantes. Ademais, qualquer discussão acerca do desenvolvimento global da plea bargaining deve necessariamente examinar o modelo norte-americano." (tradução livre).

${ }^{6}$ Importante notar que, em realidade, existem diversos modelo estadunidenses, pois cada estado tem ampla liberdade legislativa para regular o seu direito processual penal. Contudo, este trabalho parte-se do modelo de regras federais e busca-se definir algumas características comuns na generalidade dos sistemas. 
admiradores em busca da eficiência em seus sistemas de justiça, lotados de processos e criticados pela morosidade no julgamento.

Tendo-se ciência de que a pretensão de descrever o modelo processual penal estadunidense de modo detalhado vai além das possibilidades deste trabalho, aqui serão analisados pontos pertinentes ao estudo da plea bargaining e das circunstâncias que propiciaram sua expansão, ao passo que as condenações criminais em tal país são obtidas por meio de tal mecanismo em até 98 a cada cem casos, conforme a região estudada (FISHER, 2003, p. 223).

Dentro da lógica desse sistema da common law, após uma fase inicial investigatória, na qual atuam a polícia e a promotoria de justiça, esta última oferecerá a acusação formal contra o imputado, que deverá permanecer em juízo a fim de formalizar o plea. Neste comparecimento inicial ao juízo, o acusado pode declarar-se culpado - guilty plea - ou inocente - not guilty plea. Conforme Marcella Nardelli (2014, p. 341), inclusive, há certas jurisdições em que se admite a manifestação do acusado pelo desinteresse em impugnar a acusação, sem que isso signifique a assunção da culpa, é o denominado nolo contendere plea. Segundo a autora, os efeitos dessa manifestação no tocante à condenação, todavia, equiparam-se aos de um guilty plea, estando a distinção relacionada aos efeitos em relação a eventuais ações civis baseadas nos mesmos fatos.

Nesse contexto, observa-se que o processo penal dos Estados Unidos permite a declaração judicial de culpa do acusado, com o fito de encerrar o procedimento em seu comparecimento inicial em juízo, o que é chamado de guilty plea (HENDLER, 1996, p. 195). Ressalta-se que, ao se declarar culpado, o acusado permite a sua própria condenação e a aplicação da pena, cuja dosimetria é discutida em uma audiência. Caso o acusado declare-se inocente, o caso será levado ao tribunal do júri e tal declaração pode ser vista como o gozo do acusado ao direito de presunção de sua inocência. Assim, caberá à promotoria provar o teor de sua acusação além de qualquer dúvida razoável, perante o júri.

Resta clara, assim, a diferença entre o guilty plea norte-americano e a confissão do civil law, de forma que ele autoriza a aplicação imediata da pena, como alternativa ao processo, implicando disposição sobre o objeto do processo (GROSSI, 2015, p. 142). Já a confissão, no sistema romano-germânico, dentro do devido processo legal, tem valor de elemento de prova que será livremente apreciada pelo julgador, ao lado das demais provas (SCHUNEMANN, 2013, p. 251). O guilty plea representa o reconhecimento da culpabilidade

\footnotetext{
${ }^{7}$ Sobre as discussões acerca dos sistemas processuais e, especialmente, sobre as características do sistema adversarial em relação aos modelos continentais, ver: VASCONCELLOS, 2015c, p. 138-148.
} 
com relação aos fatos imputados, aceitando a imposição imediata de uma pena, renunciando a direitos fundamentais e não impondo a carga probatório ao acusador, ou seja, inutiliza-se o processo em sua essência (TURNER, 2009, p. 08).

Tendo em vista o fim precoce da quase totalidade dos casos criminais nos Estados Unidos, a admiração frente à efetividade de tal sistema se deve não pela sua conformidade com os valores do Estado de Direito, mas pelas relativizações a direitos fundamentais que acarreta. Schünemann (2013, p. 242) esclarece que por trás do disfarce adversarial equitativo representado pelo júri, o sistema americano coloca em prática o antigo modelo inquisitorial. $\mathrm{Na}$ medida em que se admite a declaração formal da culpa como alternativa ao trâmite regular do processo, as críticas são construídas além do foco excessivo que ele confere ao eficientismo no ramo processual penal, atropelando-se o devido processo legal, de forma que os críticos focam principalmente nos bastidores da declaração, onde se desenvolve o chamado plea bargaining.

Nesse sentido, torna-se interessante ao Estado (e aos atores do sistema criminal) que os índices de resolução antecipada dos processos mantenham-se em altas escalas, tendo em vista que, conforme Barbosa Moreira (2001, p. 97-98), de um lado, o promotor precisa convencer seu eleitorado de que desempenhou eficazmente sua função, o que é feito pelo alto número de condenações alcançadas mais facilmente pela via consensual. Por outro lado, os magistrados veem o mecanismo como forma de redução da carga de trabalho. Inclusive, a barganha favorece os advogados que se sentem mal preparados para enfrentar os debates do trial, induzindo seus clientes a aceitarem solução que entendem ser menos perigosa. Trata-se de uma "simbiose burocrática" que permeia as relações de poder favorecidas pelo mecanismo da barganha, o qual privilegia os interesses daqueles que têm poder no sistema criminal em desfavor da parte mais fragilizada, o acusado (VASCONCELLOS, 2015a, p. 159-164; HESSICK e SAUJANI, 2002, p. 211).

Assim, questiona-se a desnaturalização das premissas do processo penal democrático, como as garantias do devido processo legal, a fim de adotar o modelo que prima pela eficiência baseada no consenso. Nesse sentido, os altos custos dessa substituição são questionados por críticos com relação ao sistema consensual adotado nos Estados Unidos, os quais travam discussões com os admiradores da eficiência que tal sistema representaria. Segundo Alschuler (1981, p. 691, tradução livre):

"Minha tese simplesmente aponta que os interesses dos administradores do sistema de justiça criminal são mais influentes do que eles deveriam e precisavam ser. A premissa fática que fundamenta a maioria das defesas da plea bargaining - de que os advogados de defesa são representantes quase perfeitos para seus clientes e de que promotores são representantes quase perfeitos ao interesse público - é consideravelmente imprecisa". 
Em primeiro lugar, ressalte-se que o principal ponto de tensionamento é a coação inerente ao modelo de processo penal negocial. Assim, se torna ainda mais crítica a situação nos casos fracos para a acusação do ponto de vista probatório, ou quando a defesa não está disposta a negociar, o que obriga o promotor a ser mais incisivo em sua proposta. Nesse contexto, observam-se algumas práticas de constrangimento e ameaça de sobreimputação ou excesso de acusação (overcharging), as quais se praticam mediante sobrecarregamento da imputação com pluraridade de condutas, chamada horizontal overcharging, pela elevação da quantidade de sanção a ser aplicada denominada vertical overcharging, ou ainda pela ameaça de aplicação de pena capital, quando admitida (NARDELLI, 2014, p. 345).

Evidencia-se, nesse contexto, que a barganha pode ser convertida em um mecanismo de pressão (BARBOSA MOREIRA, 2001, p. 97). Ou seja, faz-se com o que os acusados abram mão de seus direitos ao devido processo legal e presunção de inocência, caso contrário restariam mal vistos por um sistema aparentemente célere, eficiente e adversarial de justiça penal. Diante desse jogo de poderes, Schünemann (2009, p. 410) aponta que não há garantia de um consenso, mas o que ocorre na prática é um mero compromisso, ao qual a parte mais fraca o acusado - deve aderir, por necessidade, ao ponto de vista da parte mais forte, a promotoria. Pode-se afirmar, com toda a certeza, que o consenso no processo penal é um mito (CASARA, 2015, p. 190).

Assim, fica evidente a desigualdade no patamar das partes envolvidas no acordo, ou seja, o órgão acusador faz a proposta considerando os riscos da condenação e as complexidades do caso racionalmente, enquanto que o acusado, ansioso e sob pressão, pode ser induzido a declarar sua culpa, ainda que seja inocente (GIACOMOLLI, 2006, p. 103). Ressalta-se ainda a disparidade entre as sanções aplicadas ao se comparar o que se declara culpado antecipadamente (normalmente sujeito a penas brandas) e o que eventualmente se vê̂ condenado após o trial (sujeito a penas excessivamente severas) em relação à prática de infrações semelhantes. Este cenário, conforme Marcella Nardelli (2014, p. 346), resulta no descrédito no sistema como um todo, bem como em uma sensação de impunidade por parte da vítima, uma vez que não se pode falar em uma determinação séria da pena nesse contexto de atenuação das reprimendas após a realização do acordo.

Aqui cabe ressaltar uma segunda crítica normalmente apontada pelos autores em relação à barganha, inserida em um sistema que é, em tese adversarial, e que presume isonomia entre as partes em disputa, acabando por representar, em verdade, características inquisitoriais devido a algumas de suas características (VASCONCELLOS, 2015b, p. 262-276). Como primeira característica, registra-se que o Ministério Público, pelo mecanismo da barganha, vol.09, n. 03, Rio de Janeiro, 2016. pp. 
acaba por conquistar um grande poder de discricionariedade ao determinar as infrações a serem imputadas e as penas a serem aplicadas pelo Tribunal.

Inclusive, com a entrada em vigor das Federal Sentencing Guidelines, criadas com o escopo de limitar a discricionariedade do magistrado ao sentenciar no fim do procedimento penal, evitando o tratamento desigual entre réus que tivessem cometido crimes semelhantes, o poder de discricionariedade do juiz acabou se esvaziando. Isso porque essas guidelines, ao estabelecerem parâmetros para a fixação da pena para cada hipótese concreta, retiraram qualquer indeterminação que poderia haver quando o magistrado sentenciasse. Da mesma forma, o referido mecanismo vinculou algumas hipóteses de fixação de pena abaixo do mínimo previsto, caso a promotoria requeresse, o que reforçou a barganha, e consequentemente o poder discricionário ministerial. O protagonismo, dessa forma, que era compartilhado entre magistrado e promotor, acabou sendo transferido integralmente ao promotor, que pode manipular a imputação e vincular o juiz a uma pena mais branda. Tal concentração de poderes nas mãos do acusador remete ao sistema inquisitório.

A segunda característica da barganha que remete ao sistema inquisitório é a fonte do material probatório utilizado como base para as negociações. $\mathrm{O}$ órgão acusador se sentirá mais seguro ou não para fazer a proposta conforme suas chances de sucesso no trial e a complexidade do caso, e essa chance de sucesso será maior caso ele reúna provas robustas contra o acusado advindas da fase investigatória (FERNANDES, 2005, p. 307). Sendo essas provas robustas, não serão feitas muitas concessões ao acusado em troca de sua declaração de culpa, o que se daria de forma contrária caso o material probatório não fosse forte o suficiente, de forma que o promotor deveria fazer maior esforço para conquistar o guilty plea (NARDELLI, 2014, p. 347).

Em terceiro lugar, conforme apontado pela doutrina crítica, além do contraditório, o plea bargaining intrinsecamente viola o conteúdo material das garantias do processo. Isso ocorre porque as negociações se dão externamente sobre o juízo oral e, em regra, sem a participação do acusado, mediante diálogo (ou, em muitos casos, somente ameaças) entre promotor e advogado. $\mathrm{O}$ acusado perde, assim, a condição de sujeito de direito, na medida em que é completamente mediatizado por seu advogado (SCHUNEMANN, 2013, p. 253).

Conclui-se, assim, que a justiça negociada não é resultado do modelo acusatório, o que seria uma tese essencialmente infundada. Segundo Illuminati (2008, p. 160, tradução livre): 
Com efeito, conforme aduz Ferrajoli (2010, p. 749), o sistema negocial viola os cinco princípios do processo penal garantista: (i) o nexo causal e proporcional entre delito e pena, tendo em vista que a medida da sanção não dependerá da gravidade do delito, mas antes da habilidade negociadora da defesa, do espírito aventureiro do imputado e da discricionariedade da acusação; (ii) os princípios de igualdade, certeza e legalidade penal, vez que não existe critério legal que condicione a atuação do Ministério Público e que discipline o jogo entre ele e o acusado; (iii) a inderrogabilidade do juízo, tornando a jurisdição e suas garantias infungíveis, como também da obrigatoriedade da ação penal e indisponibilidade das situações penais, burladas pelo poder do Ministério Público de decidir sobre a liberdade do acusado que se declara culpado; (iv) a presunção de inocência e a carga probatória da acusação, negadas pela primazia que se atribui à confissão interessada e pelo papel de corrupção do suspeito que se encarrega a acusação quando não a defesa; (v) o princípio do contraditório, que exige o conflito e a separação de funções entre as partes processuais. A própria natureza do interrogatório, segundo o autor, resta controvertida, uma vez que não é meio de instauração do contraditório por meio da exposição da defesa e a contestação da acusação, mas sim relação de força entre investigador e investigado, na qual o primeiro não tem que assumir obrigações probatórias mas sim pressionar o segundo e recolher suas autoincriminações.

\section{As propostas de expansão da justiça criminal negocial no brasil.}

Após a introdutória análise crítica do modelo negocial a partir do exemplo estadunidense, passa-se ao estudo do cenário brasileiro, o qual, além de compartilhar inúmeras das problemáticas acima expostas, finda por ter a situação agravada em razão da desigualdade e da seletividade inerente ao seu sistema de justiça criminal. A barganha viola, em essência, as premissas de qualquer ordenamento jurídico, mas, por certo, suas consequências serão ainda mais devastadoras em razão das características patológicas do sistema penal brasileiro.

Inicialmente, a Lei $\mathrm{n}^{\mathrm{o}}$ 9.099/95 introduziu o consenso no campo da aplicação do direito, mas ela o fez de forma restrita, tendo em vista que as soluções alternativas processualmente previstas para as infrações de menor potencial ofensivo (com penas máximas de até dois anos), pactuadas entre ofensor e ofendido (composição penal) ou entre sujeitos processuais (transação penal), não resultam no reconhecimento da culpa (ao menos teoricamente) e não podem ocasionar a aplicação de penas privativas de liberdade.

Por outro lado, o PLS $156 / 09^{8}$ aprofunda a previsão de instituições processuais que

${ }^{8}$ O PLS 156/2009 já foi aprovado pelo Senado e segue para votação na Câmara dos Deputados. Ao ser distribuído na Câmara dos Deputados, recebeu o número Projeto de Lei 8.045/2010, ao qual foi apensado o 
aplicam o consenso em matéria penal, institucionalizando soluções negociadas nos conflitos penais de um modo mais amplo. ${ }^{9}$ Nesse contexto, foi desenhado o "procedimento sumário", o qual registra a possibilidade de acordo sobre a pena entre as partes processuais, apresentandose como uma das grandes propostas da comissão dos juristas responsáveis pela elaboração do projeto, cujo objetivo seria, em tese, compatibilizar o novo código à Constituição Federal (COUTINHO, 2011, p. 20; BIZZOTTO, 2011, p. 09-10).

O referido Projeto de Lei prevê no artigo 283 que, até o início da instrução, antes da audiência de instrução, debates e julgamento, já cumpridas as disposições do rito ordinário, o Ministério Público e o acusado, por seu defensor, poderão requerer a imediata aplicação de pena nos crimes cuja sanção máxima cominada não ultrapasse oito anos (CASARA, 2001, p. 149). De acordo com a redação aprovada na Comissão de Constituição e Justiça, para que o acordo pudesse se configurar, deveriam estar presentes os seguintes requisitos: a confissão, total ou parcial, em relação aos fatos imputados na inicial acusatória; o requerimento de que a pena privativa de liberdade fosse aplicada em seu patamar mínimo previsto; a manifestação das partes, expressamente, dispensando a produção das provas que elas tenham indicado.

Ao permitir a simplificação da persecução penal, resultante da renúncia da cognição, bem como da formação dialética da prova, o instituto da barganha representa, nesse sentido, mais do que mero procedimento, na acepção técnico-processual, de conjunto de atos processuais sucessivos e coordenados, unidos por vínculo teleológico, o qual normalmente seria viabilizar provimento jurisdicional de mérito. Seria, na verdade, um instituto inédito no Brasil, permitindo às partes processuais "consensualmente" dispor sobre o próprio processo criminal (MALAN, 2010, p. 02), permitindo a aplicação de pena privativa de liberdade sem comprovação da culpabilidade do acusado.

Esta tendência de "sumarização" insere-se em um amplo contexto dos diversos países latino americanos de reforma legislativa processual penal (CASARA, 2011, p. 149), contudo, no Brasil, declarou-se que o objetivo do PLS 156/09 seria a adequação do sistema processual penal ao modelo acusatório adotado pela Constituição Federal.

Ainda que se declare a busca de adequação do sistema processual penal à Constituição, a adoção do "procedimento sumário", paradoxalmente, privilegia o utilitarismo processual,

Projeto de Lei n. 7.987/2010, de autoria do Deputado Federal Miro Teixeira e que objetiva também a reforma do Código de Processo Penal.

${ }^{9}$ O PLS 156/09 também prevê modificações em relação ao procedimento sumaríssimo aplicado a infrações de menor potencial ofensivo, revogando as disposições da Lei 9.099/95 e impondo inovações em sua sistemática. Contudo, neste trabalho focar-se-á o mecanismo do "procedimento sumário", em razão de sua marcante tendência como expressão da barganha no processo penal. Sobre as inovações ao procedimento sumaríssimo, ver: LEITE, 2013, p. 193-201. 
relacionando-se à ideia do combate à criminalidade a qualquer custo (LOPES JR., 2006, p. 49). Busca-se processo mais célere e eficaz, diminuindo as garantias processuais dos cidadãos, tendo em vista o interesse estatal de mais rapidamente apurar e apenar condutas sem preocupações com o respeito a direitos e garantias fundamentais. Ou seja, o processo penal inverte por completo a sua lógica essencial, deixando de se instrumentalizar como limite ao poder punitivo estatal (VASCONCELLOS, 2015, p. 163). O Estado transfere ao indivíduo a responsabilidade pela falência do sistema criminal (DUARTE e MARQUES, 2008, p. 67).

O legislador, todavia, ao condicionar o procedimento sumário à resposta da sobrecarga do judiciário, aceita-a como uma realidade dada, e não como fruto de uma política criminal equivocada ou perversões inquisitoriais. Não se busca, nesse sentido, a transformação da realidade, adequando-se a ela, de forma que a eliminação da atividade probatória resulta na rapidez da prestação jurisdicional, transformando antigas prisões provisórias em execuções definitivas da pena, prescindindo-se de investigação preliminar e diminuindo o volume de trabalho das agências estatais atuantes na persecução penal (CASARA, 2011, p. 150). Consequentemente, aceita-se a realidade e as perversões inquisitoriais que a sustentam.

Nesse sentido, o procedimento sumário previsto pelo PLS 156/09 é vastamente criticável, ignorando a inexistência de provas ou a existência de confissões absurdas, de forma que se justifica tão somente pelo acordo entre as partes. Assim, o acordo para a imposição da pena resta dependente da "subjetividade própria da filosofia da consciência" (CASARA, 2011, p. 151), ou seja, o caminho até a imposição da sanção parte dos sujeitos conscientes, que reduzem a complexidade normalmente presente na persecução penal, de forma que a pena resulta tão somente de um ato de vontade. Isso faz com que o processo (e a persecução penal) transforme-se em uma ficção, condicionada à representação subjetiva das partes, em especial, e quase que exclusivamente, da vontade do sujeito que ocupa o órgão de atuação do Ministério Público. Abandona-se totalmente a ideia de um "procedimento em contraditório" (ROSA, 2005, p. 221), não havendo tentativa de comprovação fática da imputação em sede de juízo e inexistindo a legitimação cognitivista da jurisdição (FERRAJOLI, 2010, p. 40). Em realidade, pode-se afirmar que tal modelo se configura de modo profundamente distinto em relação aos procedimentos comuns previstos no ordenamento brasileiro, de modo que a denominação "comum sumário" se mostra incompatível, já que a proposta finda por introduzir um procedimento especial que exclui por completo os parâmetros comuns do processo.

\section{CRÍTICAS AO MODELO NEGOCIAL NO PROCESSO PENAL.}

\section{Disparidade de armas entre acusador e acusado e coercibilidade do} vol.09, n. 03, Rio de Janeiro, 2016. pp. 


\section{acordo.}

A barganha pressupõe apenas uma confissão previa para que haja uma condenação, a qual nem sequer precisa ser judicial, nos termos do PLS 159/09. Conforme registra Diogo Malan (2010, p. 02), dentro desse modelo, o acusado é levado a se auto-incriminar por medo e intimidação, renunciando ao julgamento conforme o devido processo legal, temendo uma sanção mais gravosa ao final do julgamento. Ainda, conforme o autor, a paridade de armas é frontalmente atacada pelo "acordo", que hipertrofia os poderes do Ministério Público, que passa a ocupar o lugar dos jurados e juiz, acumulando as funções de formular a acusação, julgar e fixar a sanção.

O poder coercitivo da proposta de barganha em meio ao processo penal é desvelado por inúmeros doutrinadores (ALBERGARIA, 2007, p. 116; ANITUA, 2005, p. 146) em razão de sanções penais abusivamente intensificadas pela recusa ao acordo, o que se costuma denominar de "preço do julgamento", "pena de julgamento" ou "tesoura sancionatória". Assim, "o argumento de que ninguém é obrigado a se autoincriminar, em razão do direito de não produzir prova contra si mesmo, torna-se letra morta se há a promessa de uma premiação com redução da sanção penal e, a contrario sensu, um agravamento na situação de quem não o fizer" (VASCONCELLOS, 2015a, p. 167-168).

Como consequência disso, inclusive, já se vê nos Estados Unidos acusações inflacionadas para serem usadas como "moeda de troca" e para intimidarem ainda mais o acusado, para que se alcance uma plea bargaining mais vantajosa ao acusador (NARDELLI, 2014, p. 345). Referida prática de ameaça a uma sobre-imputação, denominada overcharging, apresenta como consequência a vulnerabilidade do acusado desde a fase preliminar, em especial diante de medidas cautelares que lhe privam de suas fontes de renda e sobrevivência, e até mesmo de sua liberdade (PRADO, 2010, p. 154). Ou seja, tem-se um imputado enfraquecido e pressionado psicologicamente, o que torna mais "desejável" e "interessante" o acordo. Ressalta-se ainda os instrumentos de coação e até mesmo sedução que são utilizados para que se firme o "pacto", acentuando o desequilíbrio que já ocorre na relação entre as partes processuais: a ameaça de uma pena mais severa caso haja julgamento, e a promessa de uma pena mais amena caso se renuncie ao caminho tradicional.

Nesse sentido, fica evidente a desigualdade no patamar das partes envolvidas no acordo: o órgão acusador faz a proposta considerando os riscos da condenação e as complexidades do caso racionalmente, enquanto que o acusado, ansioso e sob pressão, pode ser induzido a declarar sua culpa, ainda que seja inocente. Assim, conforme já exposta 
anteriormente, há que se registrar a disparidade entre as sanções aplicadas ao se comparar quem se declara culpado antecipadamente (normalmente sujeito a penas brandas) e quem eventualmente vê-se condenado após o trial (sujeito a penas desproporcionalmente severas) em relação à prática de infrações semelhantes.

Logo, resta claro que a barganha viola profundamente o núcleo essencial da garantia da paridade de armas, ao hipertrofiar os poderes do acusador (MALAN, 2010, p. 02), o qual, na prática, substitui juiz e jurados, concentrando os poderes de formular a acusação, julgar o caso e fixar a pena. Nesse contexto dá-se um “jogo", em que o resultado - condenação ou absolvição - não depende de provas, mas da persuasão do adversário para "aceitar" o acordo, de forma que o uso das providências cautelares com fim distinto do resguardo processual mostra-se uma poderosa arma. Nesse sufocamento do investigado, enfraquecido psicologicamente, torna-se mais desejável o acordo, operando-se uma espécie de "radar de infrações penais desconhecidas" recolhidas por providências cautelares de modo semelhante a investigações inquisitoriais da Idade Média (PRADO, 2010, p. 154). Logo, o comportamento que se pode esperar do acusado na negociação penal também se aproxima do processo característico da Inquisição: a confissão.

Diante da coação inerente à sistemática da barganha e do empoderamento da parte acusadora na justiça criminal, o processo penal tem desvirtuada sua premissa política fundamental, deixando de ser um mecanismo para evitar a condenação de inocentes. Diversos estudos demonstram claramente que a justiça criminal negocial não é aplicada consensualmente somente aos acusados que seriam condenados de qualquer modo ao final do transcorrer do "processo normal”, ou seja, o "'problema dos inocentes' não é excepcional, mas perene nas relações de poder que envolvem as negociações na justiça criminal" (VASCONCELLOS, 2015a, p. 174-175).

\section{Descaso em relação a garantias processuais: "quando" e "como julgar" substituídos pelo "não julgar”.}

Submissão à jurisdição: nulla culpa sine iudicio esvaziado por completo com a barganha.

A garantia processual da submissão à jurisdição, pressuposto de todas as demais, pode ser entendida em dois sentidos, no sentido estrito, expressa pela tese nullum iudicium sine accusatione, sine probatione et sine defensione, de forma que o juízo signifique uma exigência do conjunto das garantias penais ou substanciais; ou amplamente, expressa pela tese nulla vol.09, n. 03, Rio de Janeiro, 2016. pp. 
poena, nullum crimen, nulla lex poenalism nulla necessitas, nulla iniuria, nulla actio, nulla culpa sine iudicio, requerendo-se o conjunto das garantias processuais ou instrumentais (FERRAJOLI, 2010, p. 495). Assim, referida garantia aduz a necessidade do processo penal para aplicação de sanção, e também, em sentido amplo, como garantia orgânica da figura e do estatuto-juiz (DUARTE e MARQUES, 2008, p. 71).

Por meio do "cognoscitivismo processual", Ferrajoli (2010, p. 40-41) aponta a atividade do magistrado como cognitiva (em relação aos fatos) e recognitiva (em relação ao direito aplicável), de forma que o pronunciamento judicial deve vir motivado fática e juridicamente para que seja devidamente justificado e motivado. Para tanto, a estrita legalidade deve estar conectada ao princípio da estrita jurisdicionalidade, o qual exige dois preceitos, a verificação ou refutação da hipótese acusatória e a necessidade de comprovação empírica.

Contudo, a barganha, e de uma forma geral, a justiça negociada, violam a inderrogabilidade da justiça, impedindo que se concretize a garantia da jurisdição, no sentido de infungibilidade e indeclinibilidade do juízo, que assegura a todos o livre acesso ao processo e ao poder jurisdicional (LOPES JR., 2006, p. 139). Isso ocorre na medida em que o Estado é afastado das relações sociais, assistindo na plateia o conflito. A lógica da negociação impede que a aplicação da pena passe pelo controle jurisdicional e pelos limites da legalidade, que restará nas mãos do órgão acusador, ditada pela sua discricionariedade.

A justiça criminal negocial, em última análise, é exatamente o não-processo, é a negação da ideia basilar de reconstrução dos fatos, a partir da carga probatória imposta à acusação, para verificação do caso penal. Portanto, ela "rompe, em última análise, com a própria noção de processo, uma vez que se mostra fundamentalmente falacioso o argumento de que a sanção penal seria imposta em atenção à jurisdicionalidade motivada: os acordos consensuais entre acusação e defesa ocasionam a renúncia ao processo como instrumento de aplicação do direito e contenção de arbitrariedades” (VASCONCELLOS, 2015a, p. 194).

Presunção de inocência e desvirtuamento na distribuição das cargas probatórias no processo penal negocial.

A presunção de inocência é exigida para que se concretize o princípio da submissão à jurisdição, supondo este último que tal presunção se dê até o momento da condenação determinada pelo trânsito em julgado (FERRAJOLI, 2010, p. 505). Trata-se da primeira e essencial garantia que o procedimento confere ao cidadão, sendo ela a presunção "até a prova em contrário". Nesse sentido, registra-se que tal princípio é produto de uma opção garantista a favor da proteção da imunidade dos inocentes, mesmo que isso tenha como custo a impunidade 
de algum culpado, já que o maior interesse da sociedade é que todo e qualquer inocente seja protegido. Ele foi, juntamente com o princípio de jurisdicionalidade, consagrado na Declaração dos Direitos do Homem, de 1789. No direito brasileiro, a presunção de inocência está consagrada no artigo $5^{\circ}$, LVII da Constituição Federal. A garantia aqui tratada é o princípio reitor do processo penal, podendo-se aferir a qualidade de um sistema processual mediante o nível de observância dela (LOPES JR., 2006, p. 185).

A presunção de inocência implica numerosas consequências no tratamento da parte passiva, na carga da prova, por parte da acusação, e na obrigatoriedade de que a constatação do crime, bem como que a aplicação da sanção, sejam mediante processo com todas as garantias, culminando com uma sentença fundamentada. Isso expressa a presunção de inocência como pressuposto da condição humana (CARVALHO, 2005, p. 14), devendo ser maximizada em todos seus aspectos, mas inclusive no que diz respeito à carga probatória e às regras de tratamento do imputado.

Ao tratar do atropelamento da presunção de inocência pela plea bargaining, Lucian Dervan e Vanessa Edkins (2013, p. 17) registram que hoje quase 97 por cento das condenações sistema penal americano resulta dos plea guilty, mas que não resta claro qual parcela dessas condenações é composta por inocentes do delito pelo qual foram acusados. Todavia, é fato que o controle da barganha realizado pelo magistrado é fortemente atingido por uma presunção de culpabilidade, havendo um comprometimento prévio do julgador com a acusação (HEUMANN, 1981, p. 58-61; TULKENS, 2005, p. 710). Nesse cenário, resulta impossível distinguir as funções de acusador e julgador na medida em que o Ministério Público acaba por tomar para si funções do juiz ao definir o mérito do julgamento, tendo em vista que, em um ambiente de negociações, compete a ele oferecer a proposta de acordo, restando ao juiz mera homologação formal (LOPES JR., 2002, p. 120).

Todavia, ao permitir a simplificação da persecução penal, resultante da renúncia da cognição, bem como da formação dialética da prova, o "procedimento sumário" proposto no PLS 156/09, que permite às partes processuais consensualmente disporem sobre o próprio processo criminal, autoriza a aplicação de pena privativa de liberdade sem comprovação da culpabilidade do acusado (MALAN, 2010, p. 02). Assim, resta patente a inconstitucionalidade do referido instituto, que inclusive fere os pilares do Estado Democrático de Direito, onde os direitos fundamentais são irrenunciáveis, o que torna qualquer ato tendente à sua abdicação um atentado contra a Constituição Federal. Nesse contexto, a autonomia da vontade não pode produzir qualquer manifestação jurídica válida pretendendo dispensar garantias previstas na Constituição, o que, por si só, afasta a declaração da constitucionalidade da condenação direta vol.09, n. 03, Rio de Janeiro, 2016. pp. 
regulada pelo procedimento sumário.

Por outro lado, a barganha afasta o réu de sua posição inerente de resistência à pretensão acusatória, a qual em um processo "normal" é fortificada pela presunção de inocência, mas na justiça criminal negocial acaba por afastar o acusador de sua carga de provar perante o juízo a culpabilidade, o que seria a maior salvaguarda do acusado frente a condenações errôneas (LANGBEIN, 2001, p. 60). Ou seja, a barganha viola a presunção de inocência como regra probatória, que impõe ao acusador a carga de produzir provas lícitas para a condenação, além de qualquer dúvida razoável (GIACOMOLLI e VASCONCELLOS, 2015, p. 1111).

Isso ocorre na medida em que o acordo dissolve o contraditório no processo penal, permitindo que se imponha uma punição sem provas, e, como consequência, sem contraprova (CASARA, 2011, p. 152). Não há, nesse contexto, qualquer prova, tendo em vista que elas dificultariam o acordo, conforme já registrado por Geraldo Prado (PRADO, 2010, p. 153). E, inclusive, nos termos do PLS 156/09, é requisito para o acordo que as partes renunciem à produção de todas as provas solicitas (art. 283, §1 ${ }^{\circ}$, III). ${ }^{10}$ Como resultado, o Ministério Público acaba se desincumbindo da carga probatória quanto aos fatos alegados na denúncia, retirando do acusado a garantia que lhe era conferida pelo manto do princípio da presunção de inocência. Desse modo, inviabiliza-se por completo também a aplicação do in dubio pro reo (GROSSI, 2015, 148).

\section{Direito à defesa e ao contraditório.}

Conforme acertadamente registra Luigi Ferrajoli (2010, p. 690), a tese de que a justiça negocial e especificamente a barganha decorrem do "método acusatório" e do "processo de partes" é totalmente ideológica. Tal engano, segundo o autor, deve-se a uma confusão entre o modelo teórico acusatório, consistente na separação entre juízo e acusação, na paridade entre acusação e defesa, assim como na publicidade do juízo, e as características concretas do modelo processual adversarial dos Estados Unidos, dentre eles, a discricionariedade da ação penal e o acordo, que não têm nexo lógico com o modelo teórico.

Todavia, a discricionariedade da ação penal é paradoxal em sistemas nos quais o órgão de acusação é público. Nesse sentido, a negociação entre acusação e defesa apresenta-se como

\footnotetext{
10 “ $\S 1^{\circ}$ São requisitos do acordo de que trata o caput deste artigo: I - a confissão, total ou parcial, em relação aos fatos imputados na peça acusatória; II - o requerimento de que a pena privativa de liberdade seja aplicada no mínimo previsto na cominação legal, independentemente da eventual incidência de circunstâncias agravantes ou causas de aumento da pena, e sem prejuízo do disposto nos $\S \S 20$ e 30 deste artigo; III - a expressa manifestação das partes no sentido de dispensar a produção das provas por elas indicadas." 
oposta ao contraditório, própria do modelo acusatório, e reclama práticas persuasórias consentidas pelo segredo, em uma relação intimamente comparável à inquisição (LANGBEIN, 1978, p. 12-22). Ou seja, não se pode falar em qualquer contraditório quando as partes estão em nítida disparidade, ressaltada pelas relações patológicas inerentes ao processo penal negocial. Conforme Alschuler (1981, p. 657): “Uma característica dos sistemas jurídicos justos é que há uma minimização dos efeitos das escolhas táticas no resultado do processo. Em casos criminais, a extensão da punição de um acusado deve ser determinada pelo fato cometido e, talvez, por suas características pessoais, mas não por decisões após o fato e pela pressão de exercer ou não uma opção procedimental.".

Cumpre ainda ressaltar que esse cenário aponta para o fortalecimento da investigação preliminar, já que o acordo se aperfeiçoa com fundamento nos elementos produzidos na fase investigativa. Não se pode olvidar que a tal etapa é, por essência, inquisitória e que restringe a ampla defesa e o contraditório, de forma que nem sempre a defesa tem acesso total às informações. O contraditório pressupõe a confrontação pública e antagônica, em condições de igualdade entre as partes. Dessa forma, sem conhecer a totalidade das informações, a defesa não está em pé de igualdade para saber das chances de êxito se o caso for submetido a julgamento. Ademais, há uma ilegítima "hipervalorização da confissão incriminadora" (RODRÍGUEZ GARCÍA, 1997, p. 104-105, tradução livre), ocasionada pela barganha, uma vez que seu procedimento autoriza a prolação de sentença condenatória embasada fundamentalmente (e, em regra, exclusivamente) no reconhecimento de culpabilidade realizado pelo réu em troca do suposto benefício prometido pelo acusador, em um cenário agravado por ilegítimas coações e pressões.

Assim, a produção do lastro probatório que determinaraì a condenação do réu ocorre na fase pré-processual, antes mesmo da persecução penal, sob o comando do Ministério Público, o que é denominado por Schünemann (2009, p. 408) como "apoteose do inquérito", na medida em que a prática dos acordos consiste em uma renúncia a um juízo oral, com uma condenação baseada no reconhecimento, parcial ou total, por parte do acusado, do conteúdo da instrução, o que é uma inversão de todos os valores em que se baseia toda a prática processual continental europeia. Por certo, haì aiì, conforme registra Antonio Scarance Fernandes (2005, p. 307), um "extravasamento da função da fase de investigação", acompanhado pelo atropelamento das garantias da ampla defesa e do contraditório resultantes da preponderância de atos produzidos de forma unilateral, desprovidos de controle judicial (VASCONCELLOS, 2015a, p. 160-161).

Diante desse panorama, resta evidente que o contraditório não integra a justiça consensual e, mais especificamente, a barganha, que se perfaz por meio da aplicação de pena vol.09, nº. 03, Rio de Janeiro, 2016. pp. 
sem discussão de culpa (DUARTE e MARQUES, 2008, p. 71). Não há, nesse sentido, acusação propriamente dita, tampouco defesa, de fato ou de direito, pelo imputado. Diante disso, essencial perceber que, em um ordenamento pautado pela justiça criminal negocial, há a completa distorção da atuação defensiva, fundamentalmente ocasionada pela corrupção da relação entre o réu e seu advogado diante das negociações e das supostas vantagens de eventual acordo para reconhecimento de culpabilidade. Segundo Bovino (2005, p. 80, tradução livre), "a barganha elimina todo o conteúdo possível do direito de defesa, circunstância que em si mesma permite questionar fundamentalmente a 'certeza' necessário ao Tribunal para sentenciar uma condenação". ${ }^{11}$

\section{Motivação e publicidade das decisões.}

A motivação das decisões judiciais é importante não somente para o controle da sua racionalidade, mas ainda para que se verifique o contraditório e a suficiência de provas para a condenação. Somente a partir do dever da motivação tem-se a possibilidade de avaliar se a racionalidade da decisão predominou sobre a discricionariedade do poder, conforme expressamente consagrado no artigo 93, IX, da Constituição Federal (GOMES FILHO, 2013, p. 81; LOPES JR., 2006, p. 262). Contudo, em um modelo pautado pela barganha, consagra-se a total inviabilidade de tal imposição, tendo em vista a atuação meramente burocrática do magistrado, que tão somente homologa formalmente o acordo (DUARTE e MARQUES, 2008, p. 72).

Ressalta-se que, a partir das premissas penais e processuais penais constitucionalmente e convencionalmente impostas, não se admite imposição de uma sanção criminal sem que estejam presentes a comprovação empírica dos seguintes elementos: comissão de um delito previamente tipificado em lei, necessidade de sua punição e proibição, efeitos da conduta lesivos para terceiros, caráter exterior ou material da ação criminosa, imputabilidade e culpabilidade do autor (LOPES JR., 2006, p. 262). A referida prova empírica, inclusive, deve ser levada pela acusação a um magistrado imparcial em um processo público, contraditório e com ampla defesa, legalmente estabelecido.

Nesse contexto, conforme registrado por Ferrajoli (2010, p. 49), o ponto nevrálgico de um processo penal está na dimensão do binômio saber-poder: na medida em que o processo

\footnotetext{
11 “O advogado, temeroso de que o seu aconselhamento no sentido da não aceitação da via simplificadora, com perda das vantagens oferecidas, o prejudique se houver condenação, tende a orientar o seu cliente a concordar, protegendo-se de eventual descrédito quanto ao seu conhecimento e a sua habilidade profissionais. [...] Cria-se um círculo vicioso e perigoso em que o advogado e o acusado concordam em vol.09, nº. 03, Rio de Janeiro, 2016. pp. 
objetiva comprovar se um ato realmente ocorreu na realidade empírica, o "saber" sobre o fato é o fim a que se destina o processo, enquanto isso, o poder - coação que afeta o sujeito passivo da atuação processual - é necessário para atingir o referido saber e deve ocupar papel secundário, submetendo-se a regras estritas, limitadas pela necessidade e proporcionalidade.

Logo, o poder somente estará legitimado quando baseado no saber judicial, não podendo se fundamentar em si mesmo, em um ciclo vicioso arbitrário. Pode-se concluir, assim, que a motivação efetivamente serve para o controle das decisões judiciais, porque por meio dela se expressa a razão pela qual se alcançou uma determinada conclusão sobre autoria e materialidade. A motivação acerca dos fatos permite demonstrar o "saber", que, por sua vez, limita e legitima o poder, na medida em que a sanção somente pode ser imposta a quem pode ser considerado autor de um delito (LOPES JR., 2006, p. 265).

Com relação à publicidade do julgamento criminal, a barganha, em favor de um procedimento de negociações secretas entre as partes processuais, acaba por impedir que a população efetivamente controle o sistema de administração da justiça criminal, não permitindo que se verifique se o "saber" efetivamente legitimou o poder e se a sanção foi efetivamente imposta ao autor do delito. Como consequência, a justiça criminal negocial, nas palavras de Diogo Malan (2010, p. 2), “compromete a percepção da sociedade acerca da necessária dimensão ética e transparente do processo penal, enquanto instrumento de resolução de conflitos de interesses sociais relevantes".

Nesse contexto, ressalta-se que a efetivação de acordos entre acusação e defesa resulta em negociações informais, culminando com julgamentos não públicos, sem a participação do acusado, sem sequer seja dada a mínima consideração ao contraditório, tendo em vista que, como já apontado, o lastro probatório e o conteúdo do acordo determinam-se com base nos elementos produzidos na fase pré-processual da persecução penal, sob o comando unilateral do Ministério Público. Conforme Bovino (2005, p. 72, tradução livre): “[...] a barganha permite que o Estado, com a anuência do acusado, exime-se da exigência de publicidade e participação cidadã, sem motivo legítimo algum. A barganha acarreta uma diminuição ainda maior da já reduzida exposição pública da justiça penal na sua atuação repressiva.”

\section{CONSIDERAÇÕES FINAIS}

Diante do exposto, retoma-se a problematização apontada na introdução, de modo a atentar-se às seguintes questões: 1) a barganha, como expressão da justiça criminal negocial, é

virtude do receio de uma solução negativa e não em razão de uma avaliação segura da possibilidade de condenação." (FERNANDES, 2005, p. 267). vol.09, nº. 03, Rio de Janeiro, 2016. pp. 
mecanismo compatível com a Constituição brasileira de 1988?; e, 2) o regramento proposto pelo PLS 156/2009 (PL 8.045/2010) em seu artigo 283 (procedimento sumário) é adequado à sistematização de instituto negocial diante das características do ordenamento brasileiro?

1. O mecanismo da barganha (e o "procedimento sumário" do PLS 156/09), como expressão da justiça criminal negocial, viola direitos fundamentais previstos na Constituição Federal brasileira e também premissas basilares do processo penal de um Estado Democrático de Direito, como a presunção de inocência e o devido processo legal, e não proporciona qualquer benefício ao acusado (visto que ele se torna ilusório no sistema negocial), mas sim gera um aumento exponencial da probabilidade de condenação de inocentes, o que é totalmente inadmissível. Tal instituto proposto é, portanto, inconstitucional e inadmissível à teoria do processo penal democrático (PRADO, 2012, p. 54-56; FREITAS, 2012, p. 22-24; CASARA, 2011, p. 155-157): “a adoção de um modelo processual que atravesse as garantias do devido processo legal, com a imposição de pena sem a correta aferição de culpa, não pode ser vista com bons olhos" (GROSSI, 2015, p. 171).

a. Em razão de seu poder de intimidação, fundamentalmente determinado pelo agravamento da punição em caso de recusa ao acordo, a barganha ocasiona o exponencial aumento no risco de condenação de inocentes pela justiça criminal, o que restou comprovado em estudos empíricos citados. Assim, a premissa que legitima a justificação dos institutos consensuais perde por completo sua sustentação: os mecanismos negociais não são aplicados somente àqueles acusados que iriam ser condenados de qualquer modo em eventual julgamento, ou seja, o problema dos inocentes não é excepcional, mas perene nas relações de poder que envolvem as negociações na justiça criminal.

b. Todo esse cenário que demonstra as violações acarretadas pela expansão dos espaços de consenso no processo penal resta agravado diante das circunstâncias características do campo jurídico-penal brasileiro, fundamentalmente pautado por seletividades e desigualdades na concretização do poder punitivo estatal. Assim, as críticas descritas assumem contornos alarmantes em caso de um eventual alargamento das hipóteses de cabimento da imposição de sanções penais desde o início desincumbidas da obrigação de respeito às regras do devido processo penal (VASCONCELLOS, 2015a, p. 195-208).

2. O regramento proposto pelo PLS 156/2009 (PL 8.045/2010) é temerário, tanto em vol.09, n. 03, Rio de Janeiro, 2016. pp. 
razão das incontornáveis aporias do modelo de justiça criminal negocial (expostas cabalmente neste trabalho), como pela sua insuficiência reguladora, visto que suas previsões se mostram lacunosas e inconsistentes, expandindo ainda mais os espaços de brechas para manifestações ilegítimas de poder arbitrárias.

a. Em última análise, os mecanismos de Justiça Criminal Negocial (como o "procedimento sumário" do PLS 156/2009) possuem em sua essência e em sua sistemática inerente espaços para expressão de arbitrariedades e abusos de poder. Ou seja, a barganha é um mecanismo inevitavelmente patológico ao sistema de justiça criminal de qualquer ordenamento, visto que, em última análise, torna o poder punitivo ilimitado e incontrolável. Exemplo claro disso é o panorama atual relacionado à colaboração premiada, que tem autorizado a imposição de sanções penais em "regimes diferenciados" sem previsão legal e a transformação de bens de origem ilícita em patrimônio lícito. A Justiça Criminal Negocial é incontrolável, restando evidente sua forçosa violação às premissas constitucionais e convencionais do direito processual penal, esvaziando por completo sua essência como instrumento de limitação (e legitimação) do poder punitivo estatal.

Assim, pugna-se pela exclusão da introdução de mecanismo de aplicação antecipada de sanção penal (que invariavelmente viola o devido processo legal e a presunção de inocência), denominado "procedimento sumário" no art. 283 do PLS 156/2009 (PL 8.045/2010). Importante notar que, embora não objeto específico deste trabalho, as críticas aqui expostas também se direcionam ao mecanismo denominado "barganha" do PLS 236/2012, o qual igualmente é ilegítimo e inconstitucional, devendo ser repudiado.

\title{
CRITICAL ANALYSIS OF PLEA-BARGAINING IN CRIMINAL JUSTICE: INCONSISTENCIES IN THE PROPOSED MODEL OF THE CRIMINAL PROCEDURE CODE PROJECT.
}

\begin{abstract}
This paper will perform a critical analysis of the bargained criminal justice model proposed by the Criminal Procedure Code project (PLS 156/09), called "procedimento sumário" (summary proceeding). Starting from the introductory definition of plea-bargaining and consensual criminal procedure concepts, it will develops a study of the main features of such model, from the example of USA plea-bargaining and the mechanism designed by the PLS 156/09. Based on this, it will present a critical study of the expansion of the consensual justice in the Brazilian criminal system, which constitute a problem that empty completely many essential premises of
\end{abstract} vol.09, n. 03, Rio de Janeiro, 2016. pp. 
a democratic state of law criminal procedure. Thus, starting from the "summary proceeding" of PLS 156/09 example, it will be pointed the illegitimacy of plea-bargaining as a consensual institute in criminal justice, unveiling the unavoidable unconstitutionality of this mechanism.

Keywords: Plea bargaining. Bargained Criminal Justice. PLS 159/09. Expedited procedure. Criminal procedure.

\section{REFERENCIAS}

ALBERGARIA, Pedro Soares de. Plea Bargaining. Aproximação à justiça negociada nos E.U.A. Coimbra: Almedina, 2007.

ALSCHULER, Albert W. The changing plea bargaining debate. California Law Review, $\mathrm{n}$. 69, p. 652-730, 1981.

ANITUA, Gabriel I. El juicio penal abreviado como una de las reformas penales de inspiración estadunidense que posibilitan la expansión punitiva. In: MAIER, Julio B. J.; BOVINO, Alberto (comps.). El procedimiento abreviado. Buenos Aires: Del Puerto, 2005.

BIZZOTTO, Alexandre. O Acordo Penal Condenatório: um retrato do entrechoque entre a eficiência punitiva e o minimalismo penal. In: MALAN, Diogo; MIRZA, Flávio (coord.). 70 anos do Código de Processo Penal Brasileiro: balanço e perspectivas de reforma. Rio de Janeiro: Lumen Juris, 2011. p. 01-12.

BOVINO, Alberto. Procedimiento abreviado y juicio por jurados. In: MAIER, Julio B. J.; BOVINO, Alberto (comps.). El procedimiento abreviado. Buenos Aires: Del Puerto, 2005.

CASARA, Rubens R. R. O Acordo para Aplicação da Pena: novas considerações acerca da verdade e do consenso no processo penal brasileiro. In: COUTINHO, Jacinto de Miranda; CARVAlHO, Luis Gustavo Grandinetti. O novo Processo Penal aì luz da Constituição. Análise crítica do projeto de Lei no 156/2009, do Senado Federal. Vol. 2. Rio de Janeiro: Lumen Juris, 2011

Mitologia Processual Penal. São Paulo: Saraiva, 2015.

COUTINHO, Jacinto de Miranda. Sistema Acusatório e Outras Questões Sobre a Reforma Global do CPP. In: COUTINHO, Jacinto de Miranda; CARVALHO, Luis Gustavo Grandinetti. O novo Processo Penal à luz da Constituição. Análise crítica do projeto de Lei no 156/2009, do Senado Federal. Vol. 2. Rio de Janeiro: Lumen Juris, 2011. p. 17-36.

DERVAN, Lucian; EDKINS, Vanessa. The Innocent Defendant's Dilemma: An Innovative Empirical Study of Plea Bargaining's Innocence Problem. Journal of Criminal Law and Criminology, v. 103, n. 1, p. 01-48, mai./2012.

DIAS, Jorge de Figueiredo. Acordos sobre a sentença em processo penal. O "fim" do Estado de Direito ou um novo "princípio"? Porto: Conselho Distrital do Porto, 2011.

DUARTE, Hugo Garcez; MARQUES, Leonardo Augusto Marinho. Justiça Consensual e Tutela dos Direitos Fundamentais. Revista Phronesis, n. 4, p. 65-74, Janeiro/Dezembro de 
2008.

FERRAJOLI, Luigi. Direito e razão: teoria do garantismo penal. 3. ed. São Paulo: Revista dos Tribunais, 2010.

FERNANDES, Antonio Scarance. Teoria geral do procedimento e o procedimento no processo penal. São Paulo: Revista dos Tribunais, 2005

FISHER, George. Plea Bargaining's Triumph. A history of plea bargaining in America. Stanford: Stanford University Press, 2003.

FREITAS, Jéssica O. F. de.. PLS 156/09 e o acordo para aplicação da pena. Avanço ou retrocesso? In: PINTO, Felipe M.; GONÇALVES, Gláucio F. M. (coord.). Processo \& Efetividade. Belo Horizonte: Initia Via, 2012.

RODRÍGUEZ GARCÍA, Nicolás. La Justicia Penal Negociada. Experiencias de derecho comparado. Salamanca: Ediciones Universidad de Salamanca, 1997.

GIACOMOLLI, Nereu José. Legalidade, Oportunidade e Consenso no Processo Penal. Porto Alegre: Livraria do Advogado, 2006.

VASCONCELLOS, Vinicius G. Justiça Criminal Negocial: crítica à fragilização da jurisdição penal em um cenário de expansão dos espaços de consenso no processo penal. Revista Novos Estudos Jurídicos, vol. 20, n. 3, p. 1108-1134, set.-dez. 2015. DOI: 10.14210/nej.v20n3.p1108-1134.

GOMES FILHO, Antonio Magalhães. A motivação das decisões penais. $2^{\mathrm{a}}$ ed. São Paulo: Revista dos Tribunais, 2013.

GROSSI, Ana Claudia. Pode o acordo ser uma solução para os problemas da morosidade e sobrecarga da justiça? Revista Brasileira de Ciências Criminais, São Paulo, ano 23, vol. 114, p. 133-171, mai./jun. 2015.

HENDLER, Edmundo S. Derecho Penal y Procesal Penal de los Estados Unidos. Buenos Aires: Ad Hoc, 1996.

HESSICK, Andrew; SAUJANI, Reshma. Plea Bargaining and Convicting the Innocent: The Role of the Prosecutor, the Defense Counsel, and the Judge. Brigham Young University Journal of Public Law, v. 16, p. 189-242, 2002.

HEUMANN, Milton. Plea Bargaining. The experiences of prosecutors, judges, and defense attorneys. Chicago: The University of Chicago Press, 1981.

ILLUMINATI, Giulio. El sistema acusatorio en Italia. In: BACHMAIER WINTER, Lorena (coord.). Proceso penal y sistemas acusatorios. Madrid: Marcial Pons, 2008.

LANGBEIN, John H. Torture and Plea Bargaining. The University of Chicago Law Review, vol. 46, n. 1, p. 3-22, 1978.

Comprendiendo la breve historia del plea bargaining. Nueva Doctrina Penal, Buenos Aires, 2001.

LEITE, Rosimeire Ventura. Justiça Consensual e Efetividade do Processo Penal. Belo vol.09, n. 03, Rio de Janeiro, 2016. pp. 
Horizonte: Del Rey, 2013.

LIPPEL, Mayara Cristina Navarro. Uma visão crítica da introdução da barganha no processo penal brasileiro: desvelando as mazelas do procedimento sumário previsto no PLS 156/09. 2015. Trabalho de Conclusão de Curso (Graduação em Direito) - Faculdade de Direito, Universidade de São Paulo, São Paulo.

LOPES JR., Aury. Justiça negociada: utilitarismo processual e eficiência antigarantista, In: CARVALHO, Salo de; WUNDERLICH, Alexandre (Org.). Diálogos sobre a justiça dialogal: teses e antitheses sobre os processos de informalização e privatização da justice penal. Rio de Janeiro: Lumen Juris, 2002.

Introdução Crítica ao Processo Penal (Fundamentos da Instrumentalidade Constitucional). Rio de Janeiro: Lumen Juris, 2006.

MALAN, Diogo. Sobre a condenação sem julgamento prevista no projeto de reforma do CPP (PLS nº. 156/09). Boletim IBCCRIM, São Paulo, n 207, fevereiro/2010, p.2-3.

NARDELLI; Marcella Alves Mascarenhas. A expansão da justiça negociada e as perspectivas para o processo justo: a plea bargaining norte-americana e suas traduções no âmbito da civil law. Revista Eletrônica de Direito Processual da UERJ, v. 14, n. 1. 2014.

OLIVEIRA, Rafael Serra. Consenso no Processo Penal: uma alternativa para a crise do sistema criminal. São Paulo: Almedina, 2015.

PRADO, Geraldo. Poder Negocial (sobre a pena), Common Law e processo penal brasileiro: Meta XXI, em busca de um milhão de presos!?. In: PRADO, Geraldo. Em torno da Jurisdição. Rio de Janeiro: Lumen Juris, 2010.

Campo Jurídico e Capital Científico: o acordo sobre a pena e o modelo acusatório no Brasil - a transformação de um conceito. In: PRADO, Geraldo; MARTINS, Rui Cunha; CARVALHO, Luis Gustavo Grandinetti. Decisão Judicial. A cultura jurídica brasileira na transição para a democracia. São Paulo: Marcial Pons, 2012.

ROSA, Alexandre Morais da. Rumo à praia dos juizados especiais criminais: sem garantias, nem pudor. In: CARVALHO, Salo; WUNDERLICH, Alexandre (orgs). Novos Diálogos Sobre Os Juizados Especiais Criminais. Rio de Janeiro: Lumen Juris, 2005.

SCHUNEMANN, Bernd. Cuestiones básicas de la estructura y reforma del procedimento penal bajo una perspectiva global. In: SCHUNEMANN, Bernd. Obras. Tomo II. Buenos Aires: Rubinzal-Culzoni, 2009. 2 v. p. 393-450.

Estudos de direito penal, direito processual penal e filosofia do direito. São Paulo: Marcial Pons, 2013.

TULKENS, Françoise. Justiça Negociada. In: DELMAS-MARTY, Mireille (org.). Processos Penais da Europa. Rio de Janeiro: Lumen Juris, 2005.

TURNER, Jenia I. Plea Barganing Across Borders. New York: Aspen, 2009.

VASCONCELlOS, Vinicius Gomes de. Barganha e Justiça Criminal Negocial: análise das tendências de expansão dos espaços de consenso no processo penal brasileiro. São Paulo: IBCCRIM, 2015a.

Barganha no processo penal e o autoritarismo "consensual" nos sistemas processuais: a vol.09, n. 03, Rio de Janeiro, 2016. pp. 
justiça negocial entre a patologização do acusatório e o contragolpe inquisitivo. Revista dos Tribunais, São Paulo, n. 953, mar. 2015b.

Sistemas Processuais Penais: as contribuições das visões histórica e de direito comparado para o desvelamento da essência acusatória. Revista de Estudos Criminais, São Paulo, n. 58, p. 127-152, jul./set. 2015c.

Trabalho enviado em 06 de janeiro de 2016.

Aceito em 24 de março de 2016. 